Sheep breeding is sadly neglected. The mutton sheep and particularly the Christmas lamb can be made in the South. The Shropshires, Southdowns, Dorsets, etc., will do much toward bringing up our native flocks. The great aim should be September lambs to be pushed for a Christmas market.

Now is an opportune time for southern experiment stations, agricultural colleges, and commissioners of agriculture. Every Southern State and possibly every county should be organized into a breeding association for profit and for development of special-purpose and type animals. There should be no open go-as-you-please organization. Let there be an iron-clad agreement that the best shall not be sold, but kept within the organization. Of course, there are other rules and laws to be followed explicitly and the plans suggested by W. M. Hays in his series of articles on Breeding Animals and Plants that appeared in the Breeders' Gazette might serve as a working basis.

But why should this work be commenced now in the South? The breeders are few and they could readily unite. Moreover, the livestock industry will and must grow in the South during the next decade more rapidly than ever. Consequently there is no possible chance for a decrease in the home demand for many kinds of purebred live-stock.

Suppose a Shorthorn breeders' association should be formed in Alabama or in a given part of Alabama. Just now it would contain only a few men. Let them organize for a period of 25 to 50 years. Let them select for a definite purpose, such as the dual-purpose Shorthorn. Let every breeder be compelled to breed to a selected end or purpose. Let no man sell the first, second, or third best of his herd in bull or cow except as permitted by the association. Let there be rules by which the best bulls may be shifted from one herd to another in the organization. In 25 to 50 years this organization would have a trust in truth and in fact on that special type of Shorthorn. In order to launch and perpetuate such an organization, there must be a union of the scientific man, the business man, and the practical man.

\title{
REPORT OF THE COMMITTEE ON BREEDING FIBER CROPS.
}

By L. H. DEwer, Ohairman, Department of Agriculture, Washington, D. C.

Practically all that has been done in this country in the breeding of fiber plants is included in the seed selection begun under the direction of W. M. Hays' direction at the Experiment Station at St. Anthony Park, and the selections made by Prof. Bolley at the North Dakota Agricultural College. I have full information as to the type of flax plants desired for the production of fine spinning fiber, and also the type desired for the manufacture of binder twine. These types are now produced by seed imported from Europe, and not grown more than two or three generations for fiber production in this country. 
No attempt is made in this country to maintain the type or to breed up better varieties.

What has been said about flax applies in general to hemp also. The best types of hemp are grown from seed of the second or third generation from China. The quality of Kentucky hemp is kept up by repeated importations, in small amounts, of Chinese seed. So far as I am aware, no attempt at selection of hemp seed has ever been made in this country.

\section{IMPROVEMENT OF CITRUS FRUIT VARIETIES.}

By E. J. WICKson, Chairman, College of Agriculture of the University of California, Berkeley, California.

The possibility of improvement of varieties of citrus fruits is obviously conditioned upon opportunity manifesting itself in desirability of different types, forms and characters from those now familiar to the commercial or amateur grower. It is idle in this stage of the advancement of citrus fruit production in California simply to indulge in a general exhortation of improvement or. to suggest that change is desirable because it may secure something different. It is also true, as may be insisted upon later, that radical changes in the characters of varieties, which citrus plant breeders are attaining in the eastern and southern states, are not necessarily of any local value to California, and, from our point of view, may not constitute any improvement at all. We have followed a long and devious path of our own toward the excellence which we now possess and reference to it may be instructive to newer Californians.

It was my privilege as a young man to participate in the citrus fairs which were strong promotive and directive agencies in the early development of orange and lemon growing in Southern California. I remember the first held in Riverside nearly thirty years ago. Recent comers cannot appreciate the eagerness, the effort for close and correct discrimination, the enterprise to secure everything which had promise in it and to bring it to judgment, which were characteristic of the arguments of Riverside and of the rival citrus colonies who ransacked the world to secure the golden fleece, not of Kolchis, but of citrus excellence which should prove effective in the success of their unique horticultural enterprises. The result of this world-search brought oranges and lemons from China, India, Persia, the Mediterranean islands and countries, the gulf coast of the south, the West Indies and Mexico, and from far and wide through Oceanica, until there existed in Southern California thirty years ago a larger collection of citrus fruit varieties than in any other single country under the sun. How the visitors at the fairs admired and praised; how the judges at the fairs analyzed and condemned them by dozens, reserving only a few for tentative favor. Praise was most from the idle; merciless criticism 